\title{
Asosiasi Antara Kemampuan Analogi dengan Komunikasi Matematik Siswa SMP
}

\author{
Memen Permata Azmi \\ UIN Sultan Syarif Kasim Riau: memen.permata.azmi@uin-suska.ac.id
}

\begin{abstract}
This research is a quantitative research with cross-sectional design that aims to examine the association between students 'mathematical analogy abilities with students' mathematical communication abilities. The subject of this research is 33 students of class VII in one of Junior High School of Kampar Regency of Riau Province. The instrument used is a essay test about the problem of mathematical analogy and mathematical communication. Data analysis techniques to test the association of both capabilities based on the category of contingency association test (Pearson Chi Square test and contingency coefficient). The results showed that this study was an association between students' mathematical analogy abilities with students' mathematical communication abilities. The degree of association between students 'mathematical analogy abilities with students 'mathematical communication abilities is high.
\end{abstract}

Keywords: Analog; Association; Communication.

\begin{abstract}
Abstrak
Penelitian ini merupakan penelitian kuantitatif dengan rancangan cross-sectional design yang bertujuan menelaah asosiasi antara kemampuan analogi dan komunikasi matematik siswa. Subjek penelitian ini adalah 33 siswa kelas VII di salah satu Sekolah Menengah Pertama Negeri Kabupaten Kampar Provinsi Riau. Instrumen yang digunakan yaitu tes uraian mengenai soal-soal kemampuan analogi dan komunikasi matematik Teknik analisis data untuk menguji asosiasi kedua kemampuan berdasarkan kategorinya yaitu uji asosiasi kontingensi (uji Pearson Chi Square dan koefisien kontigensi). Hasil penelitian menunjukkan bahwa penelitian ini adalah terdapat asosiasi antara kemampuan analogi dengan komunikasi matematik siswa. Derajat asosiasi antara kemampuan analogi dengan komunikasi matematik siswa tergolong tinggi.
\end{abstract}

Kata Kunci: Analogi; Asosiasi; Komunikasi.

\section{PENDAHULUAN}

Konsep mengenai kemampuan penalaran dan komunikasi matematik yang merupakan salah satu bagian dari aspek kognitif sangat menarik untuk dibahas secara mendalam karena sangat berpengaruh pada keberhasilan siswa dalam menyelesaikan masalah matematika. Kemampuan penalaran dan komunikasi matematik termasuk dalam tujuan pembelajaran matematika untuk pendidikan dasar dan menengah yang salah satunya agar siswa menggunakan penalaran pada pola dan sifat, melakukan manipulasi matematika dalam membuat generalisasi, menyusun bukti atau menjelaskan gagasan atau pernyataan matematika; serta mengkomunikasikan gagasan dengan simbol, tabel, diagram atau media lain untuk memperjelas masalah (Departemen Pendidikan Nasional, 2006). Prinsip dan standar matematika di sekolah salah satunya adalah agar siswa memiliki kemampuan penalaran dan komunikasi matematik (NCTM, 2000). Dari tujuan tersebut dalam mempelajari 
matematika siswa dituntut terlatih menggunakan kemampuan penalaran dan komunikasi matematik dalam menyelesaikan masalah matematika.

Salah satu cara yang digunakan untuk melakukan penalaran yaitu menggunakan metode analogi (Kariadinata, 2012). Menurut Halford, kemampuan analogi sebagai inti dari perkembangan kognitif terdiri dari menempatkan struktur suatu unsur untuk struktur unsur lainnya dengan hubungan yang sesuai (Loc \& Uyen, 2014). Kemudian Sumarmo mengemukakan bahwa "kemampuan analogi adalah menarik kesimpulan berdasarkan keserupaan proses atau data yang diberikan" (Sumarmo, 2013). Arti lain dari analogi adalah berbicara tentang dua hal yang berlainan dan dua hal yang berlainan tersebut diperbandingkan, jika dalam perbandingan yang diperhatikan persamaannya saja tanpa melihat perbedaan maka timbullah analogi (Kariadinata, 2012; Shadiq, 2013; Soekardijo, 1999). Inti dari penggunaan analogi dalam pembelajaran matematika menurut Holyoak adalah untuk memecahkan masalah dengan cara siswa menerapkan pengetahuan yang sudah diketahui untuk memecahkan masalah baru (English, 2004). Secara umum penalaran analogi adalah proses penarikan kesimpulan sementara dengan cara membandingkan keserupaan proses antara suatu ide/konsep yang telah diketahui dengan ide/konsep yang belum diketahui.

Jika dilihat dari sudut pandang kehidupan sehari-hari dan hubungan lintas keilmuan berpikir analogi sangat sering digunakan. Kemampuan analogi tidak hanya digunakan pada penerapan ilmu matematika, tetapi hampir semua ilmu memerlukan kemampuan analogi, seperti dalam bidang arsitektur, fisika, bahasa, dan lain sebagainya. Dalam mata pelajaran bahasa Indonesia, peribahasa merupakan salah satu bentuk analogi non-argumentatif (Kariadinata, 2012). Disamping itu, Kepler mengemukakan bahwa ia menghargai analogi melebihi dari yang lainnya, analogi merupakan guru yang sangat dipercayainya, dengan analogi kita dapat mengetahui segala sesuatu tentang rahasia alam raya (English, 1999). Kemampuan analogi juga dapat digunakan orang pada saat kapanpun dalam memperoleh pengetahuan, hal tersebut sesuai dengan pendapat Brown menyatakan bahwa 'analogy as a learning mechanism is a crucial factor in knowledge acquisition at all ages' (Loc \& Uyen, 2014).

Peran penting analogi secara khusus dalam pelajaran matematika adalah sangat penting dalam membentuk prespektif dan menemukan pemecahan masalah (Isoda \& Katagiri, 2012). Dengan kata lain analogi merupakan salah satu alat yang digunakan dalam memecahkan masalah matematika. Semakin sering siswa berlatih menggunakan analogi dalam memecahkan masalah matematika maka proses berpikir analogi siswa dalam memecahkan masalah diluar matematika atau dalam kehidupan sehari-hari akan terbentuk sehingga akan memberi manfaat bagi kehidupan dan pengembangan ilmu pengetahuan lainnya.

Pengembangan kemampuan komunikasi matematik berhubungan dengan hakekat matematika yaitu sebagai bahasa simbol yang efisien, padat makna, memiliki sifat keteraturan yang indah dan kemampuan analisis kuantitatif; bersifat universal dan dapat dipahami oleh setiap orang, dan membantu menghasilkan model matematika yang diperlukan dalam memecahkan masalah berbagai cabang ilmu pengetahuan dan masalah kehidupan sehari-hari 


\section{Al-Jabar: Jurnal Pendidikan Matematika \\ Vol. 8, No. 1, 2017, Hal 91 - 100}

(Sumarmo, 2013). Disamping itu, komunikasi adalah bagian yang esensial dalam matematika dan pendidikan matematika karena aktivitas berkomunikasi merupakan cara untuk saling bertukar gagasan dan mengklarifikasi pemahaman (Turmudi, 2008). Proses komunikasi membantu membangun makna dan kelengkapan gagasan dan membuat hal ini menjadi milik publik. Ketika siswa diminta berargumentasi untuk mengkomunikasikan hasil pemikirannya kepada orang lain secara lisan atau tertulis, mereka belajar untuk menjelaskan atau meyakinkan orang lain, mendengarkan gagasan atau penjelasan orang lain, dan memberikan kesempatan kepada siswa untuk mengembangkan pengalaman mereka. Dengan kata lain refleksi dan komunikasi merupakan proses yang saling berkaitan dalam belajar matematika. Selain itu siswa memiliki keuntungan ganda berkomunikasi pada pelajaran matematika karena mereka berkomunikasi untuk belajar matematika dan mereka belajar berkomunikasi secara matematika (Turmudi, 2009). Dipihak lain Walle mengemukakan standar kemampuan komunikasi menitikberatkan pada pentingnya dapat berbicara, menulis, menggambar, dan menjelaskan konsep-konsep matematika (Walle, 2006). Belajar berkomunikasi dalam matematika membantu perkembangan interaksi dan pengungkapan ide-ide dalam kelas karena siswa belajar dalam suasana yang aktif.

Baroody mengemukakan, sedikitnya ada dua alasan yang menjadikan komunikasi dalam pembelajaran matematika perlu menjadi perhatian yaitu 1) matematika sebagai bahasa, bukan hanya sekedar alat bantu berpikir, alat untuk menemukan pola atau menyelesaikan masalah tetapi matematika juga sebagai "an invaluable tool for communicating a variety of ideas clearly, precisely, and succinty" dan 2) sebagai aktivitas sosial dalam pembelajaran matematika, interaksi antar siswa, antara siswa dan guru (Asikin, 2002; Nurjaman, 2015; Umar, 2012).

Memiliki kemampuan komunikasi matematik bagi siswa sangat penting, hal tersebut dikemukakan Asikin bahwa kemampuan komunikasi matematik membantu siswa dalam menajamkan cara berpikir, sebagai alat untuk menilai pemahaman siswa, membantu siswa mengorganisasikan pengetahuan matematik mereka, membantu siswa membangun pengetahuan matematiknya, meningkatkan kemampuan pemecahan masalah matematik, memajukan penalarannya, membangun kemampuan diri, meningkatkan keterampilan sosialnya, serta bermanfaat dalam mendirikan komunitas matematika (Asikin, 2002; Sumarmo, 2013). Disamping itu, Collins menyatakan salah satu tujuan yang ingin dicapai dalam pembelajaran matematika adalah memberikan kesempatan seluas-luasnya kepada siswa untuk mengembangkan dan mengintegrasikan keterampilan komunikasi melalui lisan dan tulisan, pemodelan, speaking, writing, talking, drawing serta merepresentasi apa yang telah dipelajari (Asikin, 2002).

Kemampuan komunikasi matematik siswa memegang peranan penting dalam mengembangkan kemampuan penalaran analogi karena proses bernalar menggunakan analogi berkaitan dengan aktivitas menginterpretasi masalah sumber melalui bahasa sehari-hari, gambar geometri, diagram, dan simbol atau model matematik dan menilai kebenaran ide matematika baik secara lisan maupun tertulis. Demikian juga sebaliknya, dalam menjelaskan konsep atau ide matematika baik secara lisan maupun tertulis, membuat gambar geometri, 
diagram dan simbol atau model matematika lebih mudah dimengerti jika siswa mampu mencari keserupaan proses antara materi yang sedang dipelajari dengan materi sebelumnya. Hal tersebut diperkuat dari hasil penelitian Mikrayanti yaitu terdapat hubungan kuat antara kemampuan penalaran dengan komunikasi matematik. Siswa yang memiliki kemampuan penalaran matematisnya baik/sedang/kurang maka kemampuan komunikasinya baik/sedang/kurang juga (Mikrayanti, 2012). Hal tersebut sejalan dengan pendapat Mullis bahwa penalaran matematik salah satunya mencakup komunikasi matematik (Suryadi, 2005). Dengan kata lain analogi sebagai salah satu bagian dari penalaran didalammya mencakup kemampuan komunikasi matematik.

Telah dilakukan beberapa penelitian tentang hubungan antara kemampuan komunikasi dan kemandirian belajar (Rachmayani, 2014), kemampuan komunikasi dan motivasi belajar (Darkasyi, Johar, \& Ahmad, 2014), daya nalar dan analogi matematika (Kariadinata, 2012). Hock \& Cheah menyatakan bahwa "pengembangan komunikasi matematik sejatinya tidak terlepas dari kompetensi matematik lainnya yaitu penalaran, koneksi, dan problem solving”. Artinya dalam menyelesaikan masalah matematik, masing-masing kemampuan matematik tidak dapat berdiri sendiri (Dahlan, 2011). Hal tersebut diperkuat dari pernyataan Asikin bahwa memiliki kemampuan komunikasi matematik berperan dalam memajukan penalarann siswa (Asikin, 2002; Sumarmo, 2013).

Berdasarkan penelitian yang telah dilakukan sebelumnya, keterbaruan dalam penelitian terdahulu yang menyatakan terdapat hubungan antara kemampuan komunikasi dengan penalaran matematik, atau sebaliknya terdapat hubungan antara kemampuan penalaran dengan komunikasi matematik, diduga secara khusus terdapat asosiasi antara kemampuan analogi yang merupakan bagian dari penalaran matematik dengan kemampuan komunikasi matematik. Berdasarkan uraian tersebut, peneliti tertarik melakukan studi mengenai asosiasi antara kemampuan analogi dengan komunikasi matematik siswa.

\section{METODE PENELITIAN}

Penelitian ini merupakan penelitian kuantitatif dengan rancangan cross-sectional design yang bertujuan menelaah asosiasi antara kemampuan analogi dan komunikasi matematik siswa. Subjek penelitian ini adalah 33 siswa kelas VII di salah satu SMPN di kabupaten Kampar provinsi Riau. Instrumen yang digunakan yaitu tes uraian mengenai soalsoal kemampuan analogi dan komunikasi matematik yang nantinya kedua hasil tersebut akan dilakukan uji asosiasi. Penyusunan kedua tes tersebut diawali dengan membuat kisi-kisi soal yang mencakup indikator pembelajaran, indikator kemampuan analogi dan komunikasi matematik. Selanjutnya menyusun tes serta membuat kunci jawaban dan pedoman penskoran tes, kemudian memvalidasi soal.

Teknik analisis data untuk menguji asosiasi kedua kemampuan berdasarkan kategorinya yaitu uji asosiasi kontingensi (uji Pearson Chi Square dan koefisien kontigensi) (Ruseffendi, 1998). Data yang digunakan yaitu data kemampuan analogi dan komunikasi matematik siswa. Adapun langkah-langkah pengujian asosiasi yaitu: (1) Sebelum dilakukan perhitungan statistik kontingensi, data yang berasal dari skala rasio diubah menjadi skala 
nominal. (2) Memasukkan data ke tabel kontingensi. Data tes kemampuan analogi dan komunikasi matematik siswa dikelompokkan. Kriteria pengelompokan siswa berdasarkan kemampuannya dirujuk dari Sumarmo (2013) dengan beberapa modifikasi yang disajikan pada Tabel 1 (Sumarmo, 2013).

Tabel 1. Kriteria Pengelompokan Siswa Berdasarkan Kemampuan Matematik

\begin{tabular}{cc}
\hline Hasil Tes $(\mathbf{X})$ & Kategori \\
\hline $\mathrm{X} \geq 75 \%$ & Siswa dengan Kemampuan Tinggi \\
\hline $60 \% \leq \mathrm{X}<75 \%$ & Siswa dengan Kemampuan Sedang \\
\hline $\mathrm{X}<60 \%$ & Siswa dengan Kemampuan Rendah \\
\hline
\end{tabular}

(3) Menyusun hipotesis nol dan tandingannya yang berkenaan dengan permasalahan asosiasi antara kemampuan analogi dengan komunikasi matematik. (4) Menyusun kriteria pengujian hipotesis nol. (5) Melakukan perhitungan uji asosiasi kontingensi yaitu uji Pearson Chi Square $\left(\chi^{2}\right)$ dan koefisien kontigensi (C). (6) Menentukan keputusan uji hipotesis asosiasi. (7) Menentukan derajat asosiasi dua variabel yaitu dengan membandingkan nilai koefisien kontingensi $(\mathrm{C})$ dengan nilai $\mathrm{C}$ maksimum $\left(\mathrm{C}_{\text {maks }}\right)$ yang dihitung dengan menggunakan rumus yang menurut Sudjana (2005) :

$$
\mathrm{C}_{\text {maks }}=\sqrt{\frac{m-1}{m}}
$$

$\mathrm{m}=$ harga minimum antara banyaknya baris dan banyaknya kolom .

Klasifikasi derajat asosiasi dapat dilihat pada Tabel 2.

Tabel 2. Klasifikasi Derajat Asosiasi

\begin{tabular}{ll}
\hline \multicolumn{1}{c}{ Besarnya $\mathbf{C}$} & \multicolumn{1}{c}{ Klasifikasi } \\
\hline $\mathrm{C}=0$ & Tidak terdapat Asosiasi \\
\hline $0<\mathrm{C}<0,20 . \mathrm{C}_{\text {maks }}$ & Asosiasi Rendah Sekali \\
\hline $0,20 . \mathrm{C}_{\text {maks }} \leq \mathrm{C}<0,40 . \mathrm{C}_{\text {maks }}$ & Asosiasi Rendah \\
\hline $0,40 . \mathrm{C}_{\text {maks }} \leq \mathrm{C}<0,70 . \mathrm{C}_{\text {maks }}$ & Asosiasi Cukup \\
\hline $0,70 . \mathrm{C}_{\text {maks }} \leq \mathrm{C}<0,90 . \mathrm{C}_{\text {maks }}$ & Asosiasi Tinggi \\
\hline $0,90 . \mathrm{C}_{\text {maks }} \leq \mathrm{C}<\mathrm{C}_{\text {maks }}$ & Asosiasi Tinggi Sekali \\
\hline $\mathrm{C}=\mathrm{C}_{\text {maks }}$ & Asosiasi Sempurna \\
\hline
\end{tabular}

\section{HASIL PENELITIAN DAN PEMBAHASAN}

Langkah awal sebelum melakukan uji asosiasi yaitu data kemampuan analogi dan komunikasi matematik yang berbentuk skala rasio diubah menjadi skala nominal berdasarkan kriteria penggolongan kemampuan analogi dan komunikasi matematik. Kriteria penggolongannya yaitu:

Kriteria penggolongan kemampuan analogi matematik siswa dengan skor ideal 16, yaitu:

Tinggi : skor $\geq 12$

Sedang $\quad: 10 \leq$ skor $<12$

Rendah $\quad:$ skor $<10$ 
Kriteria penggolongan kemampuan komunikasi matematik siswa dengan skor ideal 15, yaitu:

Tinggi $\quad:$ skor $\geq 12$

Sedang $\quad: 9 \leq$ skor $<12$

Rendah : skor $<9$

Hasil penggolongan tersebut disajikan ke dalam Tabel kontingensi, selengkapnya dapat dilihat pada Tabel 3 berikut.

Tabel 3. Persebaran Siswa Berdasarkan Kemampuan Analogi dan Komunikasi Matematik

\begin{tabular}{ccccc}
\hline $\begin{array}{c}\text { Siswa yang Analogi } \\
\text { Matematik }\end{array}$ & \multicolumn{2}{c}{ Siswa yang Komunikasi Matematik } & \multirow{2}{*}{$\begin{array}{c}\text { Total } \\
\text { Siswa }\end{array}$} \\
\cline { 2 - 4 } & Rendah & Sedang & Tinggi & S \\
\hline Rendah & 11 & 4 & 3 & 18 \\
\hline Sedang & 1 & 4 & 2 & 7 \\
\hline Tinggi & 0 & 1 & 7 & 8 \\
\hline Total Siswa & 12 & 9 & 12 & 33 \\
\hline
\end{tabular}

Berdasarkan Tabel 3, secara eksplisit dapat dilihat persebaran jumlah siswa berdasarkan tingkat kemampuan analogi dan komunikasi matematik siswa tinggi, sedang, dan rendah. Siswa yang kemampuan analogi dan komunikasi matematiknya rendah ada 11 orang, siswa yang kemampuan analogi matematiknya rendah tetapi kemampuan komunikasi matematiknya sedang ada 4 orang, dan siswa yang kemampuan analogi matematiknya rendah tetapi kemampuan komunikasi matematiknya tinggi ada 3 orang. Siswa yang kemampuan analogi matematiknya sedang tetapi kemampuan komunikasi matematiknya rendah ada 1 orang, siswa yang kemampuan analogi dan komunikasi matematiknya sedang ada 4 orang, dan siswa yang kemampuan analogi matematiknya sedang tetapi kemampuan komunikasi matematiknya tinggi ada 2 orang. Tidak terdapat siswa yang kemampuan analogi matematiknya tinggi tetapi kemampuan komunikasi matematiknya rendah, siswa yang kemampuan analogi matematiknya tinggi tetapi kemampuan komunikasi matematiknya sedang ada 1 orang, dan siswa yang kemampuan analogi dan komunikasi matematiknya tinggi ada 7 orang.

Umumnya gambaran secara ekspilisit mengenai asosiasi antara kemampuan analogi dengan komunikasi matematik yaitu siswa yang memiliki kemampuan analogi matematik rendah maka kemampuan komunikasi matematiknya juga cenderung rendah, siswa yang memiliki kemampuan analogi matematik sedang maka kemampuan komunikasi matematiknya juga cenderung sedang, dan demikian pula pada siswa yang memiliki kemampuan analogi matematik tinggi maka kemampuan komunikasi matematiknya juga cenderung tinggi, berlaku sebaliknya. Selain itu juga diperoleh gambaran bahwa dalam mengeksplorasi kemampuan analogi matematik siswa lebih sulit dilakukan dibandingkan dengan kemampuan komunikasi matematik karena terdapat 18 siswa yang kualifikasi kemampuan analogi matematiknya rendah, sedangkan jumlah siswa yang kualifikasi kemampuan komunikasi matematiknya rendah sebanyak 12 siswa. Hal ini juga diperkuat dari 
hasil tes kemampuan komunikasi matematik yang lebih baik dari pada kemampuan analogi matematik.

Uji yang digunakan untuk mengetahui secara signifikan ada atau tidaknya asosiasi antara kemampuan analogi dengan komunikasi matematik siswa yaitu menggunakan uji asosiasi kontingensi (Pearson Chi Square dan koefisien kontingensi). Adapun hipotesis nol dan tandingannya yaitu:

$\mathrm{H}_{0} \quad$ : Tidak terdapat asosiasi yang signifikan antara kemampuan analogi dengan komunikasi matematik siswa

$\mathrm{H}_{\mathrm{a}} \quad$ : Terdapat asosiasi yang signifikan antara kemampuan analogi dengan komunikasi matematik siswa

Kriteria pengujian:

Jika nilai Sig. $(p$-value $)<\alpha=0,05$ maka $\mathrm{H}_{0}$ ditolak

Jika nilai Sig. (p-value) $\geq \alpha=0,05$ maka $\mathrm{H}_{0}$ diterima.

Ringkasan hasil analisis uji asosiasi kontingensi (Pearson Chi Square dan koefisien kontingensi) antara kemampuan analogi dengan komunikasi matematik siswa, disajikan pada Tabel 4

Tabel 4. Hasil Uji Pearson-Chi Square dan Koefisien Kontingensi Kemampuan Analogi dan Komunikasi Matematik Siswa

\begin{tabular}{cccccc}
\hline $\begin{array}{c}\text { Nilai Uji } \\
\begin{array}{c}\text { Pearson } \\
\text { Chi Square }\end{array}\end{array}$ & dk & $\begin{array}{c}\text { Nilai Koefisien } \\
\text { Kontingensi } \\
\text { (C) }\end{array}$ & Sig. & Ho & Kesimpulan \\
\hline 17,768 & 4 & 0,592 & 0,001 & Ditolak & Terdapat asosiasi \\
\hline
\end{tabular}

Berdasarkan Tabel 4, terlihat bahwa nilai sig. uji Pearson Chi Square data asosiasi kemampuan analogi dan komunikasi matematik lebih kecil dari 0,05, maka hipotesis nol ditolak. Artinya terdapat asosiasi yang signifikan antara kemampuan analogi dengan komunikasi matematik siswa. Hal ini juga sejalan dengan hasil persebaran jumlah siswa berdasarkan tingkat kemampuan analogi dan komunikasi matematik tinggi, sedang, dan rendah. Dari hasil persebaran jumlah siswa berdasarkan tingkat kemampuan dan hasil uji asosiasi dapat disimpulkan bahwa terdapat asosiasi antara kemampuan analogi dengan komunikasi matematik siswa.

Derajat asosiasi antara kemampuan analogi dengan komunikasi matematik siswa, ditentukan melalui nilai koefisien kontingensi (C) yaitu 0,592 dan nilai koefisien kontingensi maksimum $\left(\mathrm{C}_{\mathrm{maks}}\right)$ yaitu 0,816. Berdasarkan Klasifikansi derajat asosiasi pada Tabel 3.14, nilai $\mathrm{C}$ dan $\mathrm{C}_{\text {maks }}$ memenuhi kriteria $0,70 . \mathrm{C}_{\text {maks }} \leq \mathrm{C}<0,90 . \mathrm{C}_{\text {maks. }}$. Diperoleh kesimpulan bahwa derajat asosiasi antara kemampuan analogi dengan komunikasi matematik siswa tergolong tinggi.

Hasil penelitian ini diperkuat dari hasil penelitian Mikrayanti yang menyatakan terdapat asosiasi antara kemampuan penalaran dengan komunikasi matematik (Mikrayanti, 2012). Walaupun dari hasil penelitian terduhulu hanya menunjukkan asosiasi antara kemampuan komunikasi matematik dengan kemampuan penalaran matematik secara umum, 
tetapi pada penelitian ini telah membuktikan bahwa kemampuan penalaran khususnya analogi berhubungan dengan kemampuan komunikasi matematik siswa.

Asosiasi antara kemampuan analogi dengan komunikasi matematik pada penelitian ini mengandung makna, siswa yang kemampuan analogi matematiknya tinggi maka kemampuan komunikasi matematiknya tinggi pula, siswa yang kemampuan analogi matematiknya sedang maka kemampuan komunikasi matematiknya sedang pula, dan siswa yang kemampuan analogi matematiknya rendah maka kemampuan komunikasi matematiknya rendah pula. Berlaku sebaliknya, siswa yang kemampuan komunikasi matematiknya tinggi maka kemampuan analogi matematiknya tinggi pula, siswa yang kemampuan komunikasi matematiknya sedang maka kemampuan analogi matematiknya sedang pula, dan siswa yang kemampuan komunikasi matematiknya rendah maka kemampuan analogi matematiknya rendah pula.

Hasil penelitian ini diperkuat Hock \& Cheah bahwa pengembangan komunikasi matematik tidak dapat berdiri sendiri, sejatinya tidak terlepas dari kompetensi matematik lainnya, salah satunya yaitu penalaran (analogi). Lebih lanjut Mikrayanti penalaran analogi sangat relevan dengan kemampuan komunikasi matematik karena dalam membuat analogi dapat diselesaikan melalui memahami, menginterpretasikan dan mengevaluasi ide matematik secara lisan maupun tertulis (bentuk gambar, diagram, bahasa atau simbol matematik) (Mikrayanti, 2012).

Artinya dalam menyelesaikan masalah matematik, masing-masing kemampuan matematik tidak dapat berdiri sendiri. Misalnya dalam membuat analogi memerlukan kemampuan komunikasi dalam hal menginterpretasikan masalah sumber melalui gambar, diagram, simbol matematik, atau model matematik dan dalam menilai kebenaran ide matematik pada masalah sumber. Demikian juga sebaliknya, dalam menjelaskan ide, situasi, atau konsep matematika secara lisan dan tertulis, membuat gambar, diagram dan simbol atau model matematika lebih mudah dipahami jika siswa mampu mencari keserupaan proses antara materi yang sedang dipelajari dengan materi sebelumnya.

Hasil penelitian ini secara umum menyatakan bahwa kualitas kemampuan analogi matematik siswa berhubungan kualitas kemampuan komunikasi matematiknya, berlaku sebaliknya kualitas kemampuan komunikasi matematik siswa berhubungan dengan kualitas kemampuan analogi matematiknya. Dengan kata lain, kualitas kemampuan analogi matematik setara dengan kualitas kemampuan komunikasi matematik siswa.

\section{SIMPULAN DAN SARAN}

Berdasarkan hasil temuan yang telah dikemukan, adapun kesimpulan dari penelitian ini adalah terdapat asosiasi antara kemampuan analogi dengan komunikasi matematik siswa. Derajat asosiasi antara kemampuan analogi dengan komunikasi matematik siswa tergolong tinggi.

Saran yang dapat disampaikan dari hasil penelitian ini adalah dalam mengembangkan kemampuan penalaran khususnya analogi matematik siswa sebaiknya dapat juga mengembangkan kemampuan komunikasi matematik siswa secara bersamaan, atau sebaliknya 
dalam mengembangkan kemampuan komunikasi matematik siswa sebaiknya juga mengembangkan kemampuan penalaran khususnya analogi matematik secara bersamaan karena proses bernalar menggunakan analogi berkaitan dengan menginterpretasi masalah sumber melalui bahasa sehari-hari, gambar geometri, diagram, dan simbol atau model matematik dan menilai kebenaran ide matematika baik secara lisan maupun tertulis, demikian juga sebaliknya, dalam menjelaskan konsep atau ide matematika baik secara lisan maupun tertulis lebih, membuat gambar geometri, diagram dan simbol atau model matematika lebih mudah dimengerti jika siswa mampu mencari keserupaan proses antara materi yang sedang dipelajari dengan materi sebelumnya. Peneliti lain dapat menggali secara mendalam mengenai asosiasi antar kemampuan matematik lainnya.

\section{DAFTAR PUSTAKA}

Asikin, M. (2002). Menumbuhkan Kemampuan Komunikasi Matematika melalui Pembelajaran Matematika Realistik. Prosiding Konferensi Nasional Matematika XI.

Dahlan, J. A. (2011). Analisis Kurikulum Matematika. Jakarta: Universitas Terbuka.

Darkasyi, M., Johar, R., \& Ahmad, A. (2014). Peningkatan Kemampuan Komunikasi Matematis dan Motivasi Siswa dengan Pembelajaran Pendekatan Quantum Learning pada Siswa SMP Negeri 5 Lhokseumawe. Jurnal Didaktik Matematika, 1(1), 21-34.

Departemen Pendidikan Nasional. (2006). Kurikulum Tingkat Satuan Pendidikan (KTSP). Jakarta: Depdiknas.

English, L. D. (1999). Reasoning by Analogy, pada Stiff, L.V, \& Curcio, F. R. Developing Mathematical Reasoning in Grades K-12. Reston: NCTM.

English, L. D. (2004). Mathematical and Analogical Reasoning of Young Learners. London: Lawrence Erlbaum Associates.

Isoda, M., \& Katagiri, S. (2012). Mathematical Thingking How to Develop it in Classroom. Singapore: World Scientific.

Kariadinata, R. (2012). Menumbuhkan Daya Nalar ( Power Of Reason ) Siswa Melalui Pembelajaran Analogi Matematika. Infinity, 1(1).

Loc, N. P., \& Uyen, B. P. (2014). Using Analogy in Teaching Mathematics : An Investigation of Mathematics Education Students in School of Education - Can Tho University. International Journal of Education and Research, 2(7), 91-98.

Mikrayanti. (2012). Meningkatkan Kemampuan Penalaran dan Komunikasi Matematis Siswa Sekolah Menengah Atas melalui Pembelajaran Berbasis Masalah. Tesis: Sekolah Pasacasarjana Universitas Pendidikan Indonesia Bandung.

NCTM. (2000). Principles and Standards for School Mathematics. Reston: NCTM.

Nurjaman, A. (2015). Meningkatkan Kemampuan Komunikasi Matematik Siswa SMP melalui Model Pembelajaran Kooperatif Tipe Think Pair Share (TPS). DIDAKTIK, 
9(1), 1-9.

Rachmayani, D. (2014). Penerapan Pembelajaran Reciprocal Teaching untuk Meningkatkan Kemampuan Komunikasi Matematis dan Kemandirian Belajar Matematika Siswa. JURNAL PENDIDIKAN UNSIKA, 2(1), 13-23.

Ruseffendi, E. T. (1998). Statistika Dasar untuk Penelitian Pendidikan. Bandung: IKIP Bandung Press.

Shadiq, F. (2013). Penalaran dengan Analogi? Pengertiannya dan Mengapa Penting? Widyaiswara PPPPTK Matematika, 1-7.

Soekardijo, G. R. (1999). Logika Dasar Tradisional, Simbolik dan Induktif. Jakarta: Gramedia.

Sumarmo, U. (2013). Kumpulan Makalah Berpikir dan Disposisi Matematik serta Pembelajarannya. Bandung: Fakultas Pendidikan Matematika dan Ilmu Pengetahuan Alam Universitas Pendidikan Indonesia Bandung.

Suryadi, D. (2005). Penggunaan Pendekatan Pembelajaran Tidak Langsung serta Pendekatan Gabungan Langsung Dan Tidak Langsung dalam Rangka Meningkatkan Kemampuan Berpikir Matematik Tingkat Tinggi Siswa SLTP (DISERTASI). Bandung: Sekolah Pasacasarjana Universitas Pendidikan Indonesia Bandung.

Turmudi. (2008). Landasan Filosofis dan Teoritis Pembelajaran Matematika. Jakarta: Leuser Cita Pustaka.

Turmudi. (2009). Taktik dan Strategi Pembelajaran Matematika Referensi untuk Guru SMK, Mahasiswa, dan Umum. Jakarta: Leuser Cita Pustaka.

Umar, W. (2012). Membangun Kemampuan Komunikasi Matematis dalam Pembelajaran Matematika. Infinity, 1(1).

Walle, J. A. V. (2006). Matematika Sekolah Dasar dan Menengah Jilid I (Edisi terjemahan oleh Suyono). Jakarta: Erlangga. 